\title{
IDENTITY OF STREET HOMELESS PEOPLE: A GENERAL REVIEW
}

Joshi Sudarshan ${ }^{*}$

\section{Abstract}

The people, who live, eat, and conduct activities in street and public places are street homeless people. It is simply based in observation because street homeless people do not want to disclose their identity. The study is generally the qualitative library based literature review on the issues of understanding homelessness. The main objective of the study is to collect the different meanings fusing the horizon in the application to Nepalese Homelessness. The study has reviewed 109 articles. Normally poor, destitute, and mentally weak people find in street as homeless. They need proper care and absolute identity. In the context of Nepal people found in street like street children, women and mentally weak people who live and survive in street and public places are street homeless people of Nepal.

Keywords: Homeless, Identity, Street,

\section{Background}

Homelessness is a worldwide phenomenon. It means not having a home, without a home or it is the lack of a secure and satisfactory home (Robinson \& Petter, 1999). However, some other scholars define it in different ways. Street homeless people are those who routinely find themselves on the streets during the day with nowhere to go at night and many of the street homeless people eat, sleep in the street and public area like bus park, temple (Diaz, 2006). The definition of street homeless people, who do not have permanent and fixed houses, who do not have relatives with whom they can live, and who live alone or in a family unit on the streets (Aoki, 2008). The phenomenon of street homeless people gives an historical perspective of squatting and homelessness, which also face a lack of self-determination, creativity, dignity, expression and personal needs. The profiles street homeless people's location and shelters and the characteristics also (Olufemi, 1998) related with this title.

The dentition of street homeless people includes the unavailability of adequate shelter, land and security of tenure and live on the streets or other open spaces or mobile (Graham Tipple, 2005). Generally, the street homeless people are those who do not have permanent and fixed houses, who do not have relatives, who live alone or in family unit on the street. But there is not special definition $5{ }^{*}$ Mr. Joshi is associated with legal sector, is a $\mathrm{PhD}$ fellow of Tribhuvan University can be corresponded at lawyersj1@gmail.com 
about the street homeless people (Aoki, 2008). Exactly, the people sleep, eat, work and undertake their daily activities in the public spaces and they loss of family contact, problem of depression and isolation leads to a life of poverty. There are many reasons for these social problems (Perez-Bermudez, Magallanes-Blanco, \& Antonio, 2009).

The word Homelessness is developed by three words Home+ Less + Ness means being in no home and identity. Theoretical debates concerning 'home' sense, in continually shifting social and physical boundaries, and in geographies of exclusion (Wardhaugh, 1996). How complex meaning of street homelessness is and how important homeless is defining home or homeless or more broadly, what is normal and the society create victims on which it psychologically feeds. Street homeless people's study is important for anyone interested, in the representation of underclass, particularly studies of victimization and inner city ecology also related with sociology, geography and social policy (Hutson, 2001). According to Oxford living Dictionary the meaning of home is the place where one lives permanently, specially a member of a family or household. Similarly, homeless means having no home or people those who have no home. Therefore, people who do not have family or home are homeless people. Further homelessness is a state or a situation of people from social, political, economic and environmental problems. So living People in street due to the social and economic problem and who are homeless one the street homeless people. Going through the different researches the main causes of homelessness is due to the poverty and mentality (Barrett, Lee, Jones, \& Lewis, 1990).

According to the U.S. Department of Housing and Urban Development (HUD) of America, in January $2018,552,830$ people were counted as homeless in the United States. Of those, 194,467 (35 percent) were unsheltered" - or living on the streets - "and 358,363 (65 percent) were sheltered" in temporary housing (Johnson, 2019). Another report of The National Law Center on Homelessness \& Poverty currently estimates find out that each year at least 2.5 to 3.5 million Americans sleep in shelters, transitional housing, and public places not meant for human habitation(Center, 2015). In America homeless problem in large (the number of people literally homeless on any given night was less than 400,000) increase in the sheltered homeless population between 1984 and 1987-88 could reflect a shift of the homeless from street to shelters rather than a growth in total homelessness(Freeman \& Hall, 2013).

\section{Method and objective}

The study is generally the qualitative library based literature review on the issues of understanding homelessness. The main objective of the study is to collect the different meaning fusing the horizon in the application to Nepalese Homelessness. The study has reviewed 109 articles. 


\section{Review/ Discussion}

In Kathmandu Valley more homeless people are visible in the street and shelter homes. The cause of the homelessness are stems from housing shortages, acute poverty, physical and emotional disabilities, joblessness, economic structural change, capitalism, changes in family structure, or a niggardly welfare state(Woods, 1987). Without a place and a family to live with, a people was street homeless and these street homeless people were technically not without housing; they had addresses and places in which to sleep in street and public area(Anne, Shlay, \& Peter, 1992).A phenomenology study develops accounts of everyday activity in our surrounding life-world, because the studies find that in order to explore homeless people's intentions and activities of self-care, status, identity, causes need to position these experiences within their life-worlds. Such an approach allows me to examine street homeless people's experiences, know-how, acts, really performances, and engagements with the world and other people by empirical knowledge (Krause, 2017).

In Nepalese history the term street homeless people not exactly define but the history analysis since decades this problem is existing in Nepalese society. History reveals the Kathmandu as the capital of city of Nepal. The Kathmandu valley was found by the king Gunakamadev in the year 724 BC (Ghimire, 2014). The street homeless people history started from ancient period by the term of landless, homeless and identity less. The system of Haliya, Kamaiya, Badhuwa have been eradicated and free in Nepal. Many program like providing housing arrangement for real landless and homeless has commenced in Nepal. This program reduces the street homelessness. (Wily, 2008)

The history related with the street homeless people who are elder people, from 1938 the government (ministry of women, children and social welfare)establish the providing shelters to the elderly people who are abandoned, homeless or have no one to look after care them to establish elderly care home(Thapa, 2017). This article describes the social conditions in Hungary that have led to mass street homelessness after the change of regimes at the end of the 1980s (Nagy, 2008). In cities of developing countries the numbers of the "street homeless people" have also increased since the end of the 1990s (Aoki, 2008).

To define about the homelessness and hunger are combining the number and duration of homeless spells. There are three types of homeless people (1) the transitionally homeless, (2) the episodically homeless and (3) the chronically homeless (Greif, Barrett, Lee, \& Meredith, 2008). Explain street homelessness status is related with the significance of housing tenure, the nature of domestic relations and politics which are considered by symbolic status, roots, features, privacy, quality of life etc. The homelessness is distinguished, lack of social status and rejected. The meaning of 
homelessness is complex and multidimensional (Somerville, 1992). The study measuring the status of age, sex, economic and personal vulnerabilities of homeless people (Rossi, 1992) is still in measurable condition. Cultural additional, discriminations, globalization, economic, financial losses, freedom, habitual addiction, irresponsible family are the causes of homelessness.

Living on streets is a global problem evidenced in both developed and developing countries, (Priscilla Ribeiro Biscotto, 2016). It is a universal phenomenon. The number of people live in the street, temples, under the bridge and other unsecure areas has grown in recent decades because of widespread recession, political turmoil, increasing family disintegration, growing urbanization and heterogeneous nature of society (Greif, Barrett, Lee, \& Meredith, 2008). Homelessness is a problem in Kathmandu valley also. Many factors leading to homelessness in Kathmandu are poverty, unemployment, multiple cultures; exposure to violence, caste based social discrimination, heterogeneous society etc. Street people living out of their homes have problems of food, shelter, security and health (Raikhola, 2015 ). The problem related with psychological causes are undiagnosed psychological issue, lost housing, mental illness, natural disaster, nowhere to go, political, social tagging, social, spousal problem, unemployment, and urbanization, (Aoki, 2008).Another research said that in the world scenario street homeless people started receiving increased attention from policy makers and researchers therefore, visibility on the streets, grew substantially. Tourists can also be a kind of causes of homelessness (Badal, 2019).

Government organizations of developed country, researchers, and policy analysts have examined how and why widespread street homelessness is, the causes associated and the costs of providing services. This research is little empirical work has examined whether it is possible to decrease the number of street homeless people in Kathmandu valley and identifies necessary policies to end street homelessness (Moulton, 2013) To be poor, homeless and roofless on the streets of Calcutta may not imply the same overtones of social exclusion alienation that surround street sleeping, mental illness and homelessness has also an urban problem (Timms, 2005). Hopper and Hamberg in 1986 said that "Street homelessness as it exists today may say as much about how the system currently 'works' as it does about how it 'fails' (Wardhaugh, 1996). In this review the objective of this research is to better understand life on the streets as experienced by the homeless people, their purpose, strategies and struggles to subsist from one moment to the next, materially, socially and psychologically with lived experiences (Saxton, 1995). The problem of street homeless people are invisible but they are routinely identified in the scholarly and political spheres as individuals, typically male, who displayed certain behavioral and social characteristics like disaffiliation, transience, and poverty (Greene, 2014).

It is not only our problem but it is global social problem that induced widespread popular, academ- 
ic, and political. UN also focuses to extend its International Year of Shelter for the Homeless and David Miller, to claim that Streets to Homes was helping the City "to end street homelessness" (Greene, 2014). Suggestion is that socially supportive interventions and policies can educate and empower people who care for a street homeless relatives, helping increase caregiver satisfaction and strengthening family support to reduce the problem (Polgar, 2009).The study focuses on conducted with street and shelter to find out the reality with consciousness (Mccarthy, 2013). The prevalence of the American study provides an assessment of the numbers of people who experience street homelessness but it is difficult. The conditions of homelessness pose severe problems and counting currently homeless people poses extremely difficult. The first problem is finding people who are currently street homeless. Second those studies over represent chronic, long-term street homeless people. And the third is finding the identity and perception with case of street homeless people (Link, Susser, Stueve, \& Phelan, 1994). The analysis of the interviews will be based on the theoretical framework of phenomenology to see the understanding of the life experience or perception of street homeless peoples show daily confrontations and reveal the conflict between the desire for leaving and remaining on the streets (Olufemi, 1998).

There are Numerous Researchers describe homelessness is a complex issue in the world and can be the result of a combination of social, economic and personal factors, including domestic violence and family breakdown, unemployment, mental illness and financial stress (Mission, 2018). In another view of the PurbiyaDarshan It is termed as "Abhab\&Swobhab" (Scarcity and Attitude) make to the people homeless (Bhagawat Gita). "Paropakarayapunnyaya papaya parapidanam", as the GarudPuran and "Sarbebhawantushukhinaya" in Bhagwat Gita explain humanity is best on social welfare.

The study of Identity refers the most important questions, "Who are you? Who am I? And who are we?" This research has argued that the identity is related with the personal and social identities base on the level of identities. The identity has shown in psychological process and social cultural process. The research explains the identities as experience as real, unitary and stable based on actually constructed multiple and fluid. (Deaux \& Snyder, 2017). Identity reflects on the book "The Stanford Encyclopedia of Philosophy", where the author describes about the problem of personal identities, who am I? What am I? When did I begin? What will happen to me when I die? These are related with eastern philosophy also subject of consciousness. Personal identity contrasts with ethnic or national identity, which consists roughly of the ethnic group or nation one takes oneself to belong to and the importance one attaches to this (Olson, 2019). Another study explains about the human identity provide answers to the basic questions who am I? Where do I Belong?, and 
How do I fit? (Oyserman, 2012). Another study explains the identity as a political issue it includes national, ethical, gender and state and all humanities researcher explain on "identity" as the cultural politics of race, class, ethnicity, gender, sexuality, citizenship, and other social categories. The meaning of identity is at the heart of constructivist critiques of realism and analyses of state sovereignty (Fearon, 1999). Social identity theory has focused the causes and consequences of identifying with a social group or category like who you are and identity theory has concerned on the causes and consequences of identifying with a particular role like what you do base on roles or behaviors (Stets \& Burke, 2000).

The negative identity reflects the name of Bebarise,Khate, Magne,, Sadakchhap are now a days generalized to all street homeless people with children who work, live, sleep and spend their life and all time on the street in Nepal (Ghimire, 2014). Same as the options for the homeless to repair their negative social identity indicates some possibilities (Robinson \& Petter, 1999). The street homeless people have many identities with work, as vendors, scavengers, car watchers, "barkers," beggars, and so on, and sometimes through illegal activities such as those of snatchers, pickpockets, drug sellers and prostitutes. The street homeless are the symbolic and representative product of globalization, so the identities of street homeless people related with political, economic, social, cultural ideologies and development. (Aoki, 2008). This study discuses the base on character, categories, variable with Cultural identity of the street homeless people who have a strong homeless identity (II-Seong, 2006). To explore their identity maintenance strategies using Social Identity Theory which derived from their knowledge of their membership of a social group together with the value and emotional significance attached to that membership. It is vital that identity maintenance processes are taken on board by policy makers and practitioners dealing with the homeless. Strategies used would dire as a function of longevity of homelessness like short term and long term street homelessness (Robinson \& Petter, 1999). The term of identity related with "street children" and its various mutants such as "street kids", "street boys", "parking boys", "car -washers", "teenage beggars", "street bums", children on their own", and "mutibumba" refer to a complex phenomenon. (Unicef, 2012).

There are various grounds where the word, identity can be defined. According the United Nations concept note definition, legal identity is the basic characteristics of an individual's identity (e.g. name, sex, place and date of birth) conferred through registration and the issuance of a certificate by an authorized civil registration authority following the occurrence of birth. It is widely acknowledged to be catalytic for achieving at least ten of the Sustainable Development Goals. Recognizing that the issue of legal identity for all is of paramount importance in terms of fulfilling the Sustainable Development Agenda, it assessment of those population without valid proof of 
legal identity as well as the number of unregistered (UN, 2019). Recognition of the identity of persons is one of the means through which observance of the rights to legal personhood, a name, a nationality, civil registration, and family relationships is facilitated. In this research there is a well saying that legal identity is connected with the eligibility for citizenship of nation. It is linked with right and personality of individual. In the context of street people (Vulnerable Population) are not given priority to ensure their legal identity in the context of Nepal also. Since they are not registered, they are stateless (Gurung \& Khatiwada, 2015). There are numerous researchers describing legal identity refers to a human being's legal (as opposed to physical) personality. Legal identity may be needed to secure from access to education, to land and business registration, to getting a utility connection and obtaining passports (ADB, 2007).

As empirical study conducted to the Nepal Labor Force Survey 2008, there were about 7.77 million children in Nepal between 5 to 17 years of age, in which, $50.7 \%$ were boys and $49.3 \%$ were girls. That number has grown for broken families have been apart by xix economic hardship, leaving children to fend for themselves. Children are often seen begging, or working in the streets, cafes, petrol stations; sometimes well into the night (Khanal, 2014).

The study describes about the street children to classify and identify so many little lives: street children "," children in a street situation "," children on the street and children at risk". In Kathmandu valley they are living in different places. There are as many reasons for being on the street as there are street children. Whenever we think of the word 'Street Children' we visualize a child involved in petty trade or carrying goods, shoe shining, begging, sleeping on the corner of the street, collecting garbage, sorting the left over as their food, etc.(Ghimire, 2014).

Another research finds out the visible and invisible causes are associated with the homelessness of children, which in fact force them to spend their life on to street. The main causes are: family breakdown, poverty, natural and manmade disasters, physical and sexual abuse, exploitation by adults, urbanization, overcrowding and others (CBS, 2011). A study by CWIN in 1998 estimated that there were approximately 5,000 street children in Nepal with an estimated 300-400 new children ending up on the streets annually (CWIN, 1998). There are also a considerable number of street children in Nepal trafficking continues to be a problem. Rapid and uncontrolled development of urbanization has led to a dramatic increase in the number of street children, with children being attracted to urban area. Assume that the reasons for migration to the city are diverse but include the death of one or both parents, poverty, illiteracy, domestic abuse alongside the perceived attractions of city life. They earn form "rag pickers" and the most common reason given for being a street children were prior abuse and neglect (CWIN, 1990). 


\section{Conclusion}

In conclusion, identity of the street homelessness is the main issue of the study. It is problematic to define social as well as individual. Social identity is the real identity of the homeless people but they do not want to disclose their individual real identity. To study the issues of homeless people is challenging to define them legally but it is possible through observation and qualitative methods. Normally poor, destitute, and mentally weak people find in street as homeless. They need proper care and absolute identity. In the context of Nepal people found in street like street children, women and mentally weak people who live and survive in street and public places are street homeless people of Nepal.

\section{References}

ADB. (2007). Legal Identity for Inclusive Development.

Anne, R., Shlay, \& Peter. (1992). Social Science Research and Contemporary Studies of Homelessness. Annual Review of Sociology, Vol. 18 (1992), pp. 129-160, 129-160.

Aoki, H. (2008). Globalization and the Street Homeless in Metro Manila. Philippine Studies, Vol. 56, No. 1, Blair \& Robertson (march 2008), pp. 69-76, 69-76.

Badal, B.P. (2019). Tourism: Visit Nepal 2020, Research Nepal Journal of development Studies, $2.2,12-30$.

Barrett, Lee, Jones, \& Lewis. (1990). Public Beliefs about the Causes of Homelessness. Social Forces, Vol. 69.1, 253-265.

CBS. (2011). National Census Report. Kathmandu, Nepal.

Center, N. a. (2015). Homelessness in America: Overview of Data and Causes. America.

CWIN. (1990). Lost children, A research survey on street children in Nepal.

CWIN. (1998). Lost Children, A research Survey on street children. Kathmandu.

Deaux, K., \& Snyder, M. (2017). Identity: Personal and Social. UK: Oxford University Press.

Diaz, R. (2006). Street homelessness. London: streethomelessnessfactsheet_reformatted.doc.

Fearon, J. D. (1999). What is identity (as we now use the word)? Stanford: Stanford University. 
Freeman, R., \& Hall, B. (2013). Permanent Homelessness in America? Population Research and Policy Review.

Ghimire, L. (2014). Being on the street causes, survival stratigy and societal percepyion an emperical study of street children in kathmandu. University of Nordland, narway, 1-101.

Graham Tipple, S. S. (2005). Definitions of homelessness in developing countries. Habitat International 29 (2005) 337-352338, 337-352.

Greene, J. (2014). Urban Restructuring, Homelessness, and Collective Action in Toronto, 19802003. Urban History Review / Revue d'histoire urbaine, Vol. 43.1 , 21-37 .

Greif, Barrett, Lee, \& Meredith. (2008). Homelessness and Hunger. Journal of Health and Social Behavior, Vol. 49.1, 3-19.

Gurung, Y., \& Khatiwada, P. (2015). Legal Identity in Nepal: An Assessment of Existing Database and Recommendations for Future Directions.

Hutson, S. (2001). Sub City: Young People, Homelessness and Crimes by Julia Wardhaugh . Urban Studies, Vol. 38.8 (July 2001), pp. 1410-1411, 1410-1411.

Il-Seong, Y. (2006). Homelessness and Community Attitudes in South Korea as Compared with Japan . Development and Society, Vol. 35.2 , 217-239 .

Johnson, R. (2019). 10 facts about homelessness in America. Action Institute Powerblog.

Khanal, U. (2014). Street children in Nepal.

Krause, A. H. (2017). Care on the Street A study on practices of care among homeless people in Amsterdam . Medical Anthropology and Sociology University of Amsterdam .

Link, B. G., Susser, E., Stueve, A., \& Phelan, J. (1994). Lifetime and Five-Year Prevalence of Homielessness in the United States. Journal of Public Health December 1994, Vol. 84. 12, 1907-1912.

Mccarthy, L. (2013). Homelessness and identity: a critical review of the literature and theory. People, Place \& Policy Online (2013): 7/1, pp. 46-58. DOI: 10.3351/ppp.0007.0001.0004, 46-58.

Mission, W. (2018). Perceptions of homelessness in Australia How to make our compassion count. 
Moulton, S. (2013). Does Increased Funding for Homeless Programs Reduce Chronic Homelessness? Southern Economic Journal, Vol. 79, No. 3 (January), 600-620.

Nagy, É. T. (2008). “Man On The Street”: An Experiment In Social Justice Activism And Activist Anthropology In Hungary . Urban Anthropology and Studies of Cultural Systems and World Economic Development, Vol. 37. 2, , pp. 139-174 .

Olson, E. T. (2019). Personal Identity,The Stanford Encyclopedia of Philosophy . Metaphysics Research Lab, Stanford University.

Olufemi, O. (1998). Street homelessness in Johannesburg inner-city:a preliminary survey. Environment and Urbanization, Vol. 10. 2, 223-234.

Oyserman, D. (2012). Self-Concept and Identity. ResearchGate, 499-517.

Perez-Bermudez, C. M.-B. (2009). Citizens' Publications That Empower: Social Change for the Homeless. Development in Practice, Vol. 19, No. 4/5 (Jun., 2009), pp. 654-664, 654-664.

Polgar, M. (2009). How Are People Empowered to Help a Homeless Relative? Human Organization, Vol. 68. $4,431-438$.

Priscilla Ribeiro Biscotto, M. C. (2016). Understanding of the life experience of homeless women. Journal of school of nursing.

Raikhola, P. S. (2015 ). A Study about the Life of Street Children in Kathmandu Valley . Journal of Nepal Public Health Association, Vol. 6. 2.7, 42-53.

Robinson, A. F., \& Petter, W. (1999). Homelessness and Strategies of Identity Maintenance: A Participant Observation Study. Journal of Community \& Applied Social Psychology J. Community Appl. Soc. Psychol. 9:, 175-194.

Rossi, S. (1992). Social science Research and Contemporary studies of Homelessness. Annual Review of Sociology Vol.18, 129-160.

Saxton, S. L. (1995). Down on Their Luck: A Study of Homeless Street People. Symbolic Interaction, Vol. 18, No. 1 , 95-97.

Somerville. (1992). Homelessness and the Meaning of Home: Rooflessness or Rootlessness? International Journal of urban and Regional research, 16(4), 529-539. 
Stets, \& Burke. (2000). Identity Theory and Social Identity Theory. Social Psychology Quarterly Vol. 63, No 3, 224-237.

Thapa, S. (2017). Abandonment of elderly people in Nepal, elderly people's perspective. Diaconiauniversity of applied science, 11.

Timms, P. (2005). Is There Still a Problem with Homelessness and Schizophrenia? . International Journal of Mental Health, Vol. 34, No. 3, Homelessness and Health (II) , 57-75.

UN. (2019). United Nations Strategy for Legal Identity for All.

Unicef. (2012). A Study on Street Children in Zimbabwe. Zimbabwe: Unicef.

Wardhaugh, J. (1996). 'Homeless in chinatown': deviance and social control in cardboard city . Sociology, Vol. 30, No. 4 (November), 701-716.

Wily, L. A. (2008). Land Reform in Nepal Where is it coming from and where is it going? Kathmandu: Auther.

Woods, W. B. (1987). Homelessness in Cincinnati. Cincinnati, Ohio: Appl. Info. Res. Jostor 